\title{
Association between Serotonin-Related Polymorphisms in 5HT2A,TPHI,TPH2 Genes and Bipolar Disorder in Korean Population
}

\author{
Kwang-Yeon Choi ${ }^{1}$ \\ Ho-Kyoung Yoon ${ }^{1}$ \\ Yong-Ku Kim ${ }^{1,2} \bowtie$ \\ 1 Department of Psychiatry, \\ College of Medicine, \\ Korea University, \\ Ansan Hospital, Ansan, \\ ${ }^{2}$ Division of Brain Korea 21 \\ Biomedical Science, \\ Korea University, Seoul, Korea
}

\section{$\triangle$ Correspondence}

Yong-Ku Kim, MD, PhD

Department of Psychiatry,

College of Medicine,

Korea University,

Ansan Hospital,

516 Gojan-dong, Danwon-gu,

Ansan 425-707, Korea

Tel $+82-31-412-5140$

Fax +82-31-412-5144

E-mail yongku@korea.ac.kr

(c) This is an Open Access article distributed under the terms of the Creative Commons Attribution Non-Commercial License (http://creativecommons.org/licenses/by-nc/3.0) which permits unrestricted non-commercial use, distribution, and reproduction in any medium, provided the original work is properly cited.
Objective The aim of the present study was to examine the association between serotoninrelated gene polymorphisms and bipolar disorder in the Korean population. In addition, we sought to explore the relationship between the clinical characteristics of bipolar patients and serotonin-related gene polymorphisms.

Methods Inpatients with bipolar disorder $(\mathrm{n}=103)$ and control subjects $(\mathrm{n}=86)$ were genotyped for 5HT2A 1438A/G, tryptophan hydroxylase 1 (TPH1) 218 A/C, and TPH2 703G/T. We divided patients with bipolar disorder into two groups according to the presence of psychotic symptoms. The severity of their symptoms was measured using the Young Mania Rating Scale (YMRS) and the Brief Psychiatric Rating Scale (BPRS).

Results There were no significant differences in the genotype distributions or allelic frequencies in the three serotonergic polymorphisms between patients with bipolar disorder and normal controls. There were significant differences in genotype distributions and allele frequencies of the 5-HT2A - $1438 \mathrm{~A} / \mathrm{G}$ polymorphism between the psychotic mania group and the non-psychotic mania group (genotype: $\chi^{2}=7.50, p=0.024$; allele: $\chi^{2}=5.92, p=0.015$ ). However, after Bonferroni correction this signifact difference disappeared. We did not find significant differences in the genotype distributions or allelic frequencies in the TPH1 $218 \mathrm{~A} / \mathrm{C}$ and TPH2 $703 \mathrm{G} / \mathrm{T}$ polymorphisms between the psychotic mania group and non-psychotic mania group.

Conclusion We failed to found the statistically significant association between three polymorphisms and bipolar disorder. However, there was a trend towards association between 5-HT2A -1438A/G polymorphism and psychotic symptom in bipolar disorder. Future research should seek to clarify this association.

Psychiatry Investig 2010;7:60-67

Key Words Bipolar disorder, Mania, Polymorphism, Serotonin.

Received: November 5, 2009 Revised: January 26, 2010 Accepted: January 30, 2010

Available online: March 3, 2010

\section{Introduction}

Bipolar disorder is relatively common psychiatric illness with a lifetime prevalence of $0.5-1.0 \%{ }^{1}$ The heritability of bipolar disorder is estimated to be as high as $85 \%,{ }^{2}$ and profound efforts have been put forth in an attempt to elucidate the genetics of the illness. Nevertheless, the susceptibility genes for bipolar disorder have proven elusive. This may be due to many genes of small effect sizes contributing to the risk of developing the disorder.

Disturbance of the serotonergic system has been implicated in the etiology of bipolar disorder. A number of studies of candidate genes involved in serotonin metabolism and serotonergic transmission have been investigated.

The serotonin 2A receptor (5-HT2A) gene is located on chromosome 13q14-q21. It consists of three exons and two introns, spanning over $63 \mathrm{~kb}$. The $1438 \mathrm{~A} / \mathrm{G}$ polymorphism is located on the promoter region of 5-HTR2A, and the $102 \mathrm{~T} / \mathrm{C}$ polymorphism is located on axon 1. The $-1438 \mathrm{~A} / \mathrm{G}$ single nucleotide polymorphism (SNP) is in strong linkage disequilibrium with $102 \mathrm{~T} / \mathrm{C} \mathrm{SNP}{ }^{3}$ A $1438 \mathrm{~A} / \mathrm{G}$ polymorphism has the potential to modulate 5 -HT2A pro- 
moter activity ${ }^{4}$ and may be associated with the pathogenesis of bipolar disorder.

Several studies have examined the association between 5-HT2A receptor genes and bipolar disorder, though the results have proven inconsistent. A previous study of the Korean population suggested that the $1438 \mathrm{~A} / \mathrm{G}$ polymorphism of the 5-HT2A receptor gene promoter may be associated with the development of bipolar disorder. ${ }^{5}$ However, other studies have reported that the $5-\mathrm{HT} 2 \mathrm{~A}$ receptor $1438 \mathrm{~A} / \mathrm{G}$ is not associated with bipolar disorder. ${ }^{6,7}$

Patients who are heterozygous for $\mathrm{T}$ and $\mathrm{C}$ alleles at 102 develop bipolar disorder earlier than patients who are homozygous for the $\mathrm{C}$ allele. ${ }^{8}$ We could therefore hypothesize that if the $1438 \mathrm{~A} / \mathrm{G}$ polymorphism alters 5 -HT2A promoter activity, it may also alter the mean age of onset.

Tryptophan hydroxylase (TPH) catalyzes the biopterin-dependent monooxygenation of tryptophan to 5-hydroxytryptophan, which is subsequently decarboxylated to form serotonin. ${ }^{9}$ TPH is a rate-limiting enzyme involved in the biosynthesis of serotonin. Two TPH isoforms have been identified. The TPH2 gene is predominantly expressed in the brainstem, especially in the raphe nuclei neuron in which serotonergic neurons are the main neuronal components in a rodent model. ${ }^{10}$ The TPH1 gene is expressed predominantly in the pineal gland and, to some extent, in the peripheral tissues (duodenum, kidneys, or lungs). ${ }^{11}$

The TPH1 gene is located on chromosome 11p15.3-p14. The 218A/C SNP is reported in intron 7 of the TPH1 gene. The TPH1 gene has been implicated in several psychiatric conditions, such as bipolar disorder, ${ }^{12}$ suicidal behavior, ${ }^{13}$ alcoholism, ${ }^{13}$ and aggression-related traits. ${ }^{14}$ However, such associations were not replicated in other studies involving suicidal behavior ${ }^{15,16}$ and bipolar disorder. ${ }^{17}$ In a recent meta-analysis, the homozygous recessive genotype of the TPH1 A218C polymorphism was reported to increase the risk of bipolar disorder but not of major depressive disorder. ${ }^{18}$

The TPH2 gene is located on chromosome 12q21.1. In mice brain stems, the expression of TPH1 appears to be 150 times lower than TPH $2,{ }^{19}$ suggesting that TPH2 may play a much more important role in serotonin synthesis in the brain than TPH1. Consequently, many studies have examined the potential role of TPH2 in the development of depression, suicide, ${ }^{20,21}$ and bipolar disorder. ${ }^{21,22}$ In a postmortem study, higher levels of TPH2 expression were found in the dorsolateral prefrontal cortices of patients with bipolar disorder when compared to control subjects. ${ }^{23}$

In the present work, we tested the hypothesis of an involvement of the 5-HT2A, TPH1, and TPH2 genes in the development of bipolar disorder. In addition, we assessed the modifier role of these genes in the clinical characteristics of bipolar disorder (e.g., presence of psychotic features, age of onset, and number of episodes).

\section{Methods}

\section{Subjects}

A total of 103 bipolar patients were recruited from Korea University's Ansan Hospital. All subjects were recruited during admission. All patients with bipolar disorder met the DSMIV criteria ${ }^{24}$ for bipolar I disorder. Each patient was assessed by trained psychiatrists using a Structured Clinical Interview for DSM-IV Axis I Disorders (SCID-I) ${ }^{25}$ on the first day of their admission. In the case that patient couldn't cooperate with the interview because of rapid tranquilization we assessed the patient next day or at the latest within 3 days after admission. We excluded subjects with Axis I or II psychiatric comorbidities according to the DSM-IV, such as schizophrenia, alcohol abuse, substance abuse, or personality disorders. We also excluded subjects with significant organic brain disease or clinically significant somatic disease. We also collected data such as age of onset, duration of illness, number of illness episodes using medical records and information from relatives because patients in acute manic state could not provide reliable informations on the first day of their admission. The normal control group consisted of healthy individuals who visited Korea University's Ansan Hospital for regular health screening and volunteered to participate in this study. Participants were excluded if they had a personal or familial psychiatric history, had been diagnosed with a psychiatric illness, or had taken any kind of psychotropic medicines. A final total of 86 subjects were recruited. Written informed consent was obtained from all subjects.

We assessed the severity of manic symptoms using the Young Mania Rating Scale (YMRS) ${ }^{26}$; the severity of psychotic symptoms were assessed using the Brief Psychiatric Rating Scale (BPRS). ${ }^{27}$ The YMRS and BPRS were administered on the first day after admission. We acquired data on the clinical variables, such as number of episodes and duration of illness. Each case of bipolar disorder was categorized into one of two groups according to the presence of psychotic features. Psychotic features included grandiose delusions, auditory hallucinations, delusions of persecution, and delusions of reference. Patients were categorized in the psychotic mania group if they had any of the psychotic symptoms mentioned above during the index episode.

\section{Genotyping}

Deoxyribonucleic acid (DNA) was extracted from plasma leukocytes using the Wizard Genomic DNA Purification Kit (Promega, USA). In order to genotype the 1438A/G SNP in the 5-HTR2A gene, a polymerase chain reaction (PCR) was performed with the forward primer 5'-CTGGGTGGCATATTTCTGCT-3' (-1610 to -1591) and the reverse primer 5'-ACCAAGGGACTCCTGGTTTC-3' (-1107 to -1088).

The amplification mixture contained $1 \mu \mathrm{L}$ of $100 \mathrm{ng} / \mu \mathrm{L}$ DNA, $5 \mu \mathrm{L}$ of $10 \times$ PCR buffer, $4 \mu \mathrm{L}$ of $2.5 \mathrm{mM}$ Ex dNTP mix- 
ture, $2 \mu \mathrm{L}$ primer, $37.75 \mu \mathrm{L}$ distilled water, and $0.25 \mu \mathrm{L}$ Taq polymerase (TaKaRa, Japan). Samples were amplified using a Thermocycler (GeneAmp PCR system 2700, Applied Biosystems, Foster City, CA, USA) for 35 cycles. The thermal cycling conditions were: $94^{\circ} \mathrm{C}$ for $5 \mathrm{~min}$, followed by 35 cycles of $94^{\circ} \mathrm{C}$ for $30 \mathrm{~s}, 62^{\circ} \mathrm{C}$ for $30 \mathrm{~s}, 72^{\circ} \mathrm{C}$ for $30 \mathrm{~s}$, and ending with $72^{\circ} \mathrm{C}$ for 5 min (GenoAmp PCR system 2700, Applied Biosystems). The amplified DNA was digested with the restriction enzyme MspI (Promega, USA), which cuts at the 1438G sites. The product was electrophoresed on 3\% agarose gels and stained with ethidium bromide. Homozygous genotypes were identified by the presence of a single 513-bp band (A/A), or bands of 313- and 182-bp (G/G). The heterozygous genotype $(\mathrm{A} / \mathrm{G})$ displayed all three band sizes. In order to genotype the $218 \mathrm{~A} / \mathrm{C}$ SNP in the TPH gene, the reaction mixture consisted of $100 \mathrm{ng}$ of DNA, $2.5 \mathrm{mM}$ Ex dNTP mixture, 5 unit Ex Tag polymerase, $10 \times$ Ex Tag buffer (all TaKaRa, Japan), and 10 pmoL of each primer (forward primer: 5'-CGTCCTGTGGCTGGTTACTT-3', reverse primer: 5'-CACGCTGCAGTGCTTAACAT-3').

The thermal cycling conditions were: $94^{\circ} \mathrm{C}$ for $5 \mathrm{~min}$, followed by 35 cycles of $94^{\circ} \mathrm{C}$ for $30 \mathrm{~s}, 56^{\circ} \mathrm{C}$ for $30 \mathrm{~s}, 72^{\circ} \mathrm{C}$ for 30s, and ending with $72^{\circ} \mathrm{C}$ for $5 \mathrm{~min}$ (GenoAmp PCR system 2700, Applied Biosystems). The product size was 881-bp. After the PCR and digestion by NheI enzyme for $2 \mathrm{~h}$ at $37^{\circ} \mathrm{C}$, the digested products were analyzed on $2 \%$ agarose gel. The TPH C allele was cleaved into fragments of 337- and 544-bp, while the A allele was uncut.

In order to genotype the 703G/T SNP in the TPH2 gene, the reaction mixture consisted of $100 \mathrm{ng}$ of DNA, $2.5 \mathrm{mM}$ Ex dNTP mixture, 5 unit Ex Tag polymerase, $10 \times$ Ex Tag buffer (all TaKaRa, Japan), and 10 pmoL of each primer (forward primer: 5'-TTTTATGAAAGCCATTACACAT -3', reverse primer: 5'-TTCCACTCTTCCAGTTATTTTA-3'). The thermal cycling conditions were: $95^{\circ} \mathrm{C}$ for $5 \mathrm{~min}$, followed by $36 \mathrm{cy}$ cles of $95^{\circ} \mathrm{C}$ for $45 \mathrm{~s}, 51.9^{\circ} \mathrm{C}$ for $45 \mathrm{~s}, 72^{\circ} \mathrm{C}$ for $45 \mathrm{~s}$, and ending with $72^{\circ} \mathrm{C}$ for $3 \mathrm{~min}$ to maximize the extension (GenoAmp PCR system 2700, Applied Biosystems). The product size was 881-bp. After the PCR and digestion by NheI enzyme for $4 \mathrm{~h}$ at $37^{\circ} \mathrm{C}$, the digested products dyed with ethidium bromide were analyzed on 3\% agarose gel. The TPH G allele was cleaved into fragments of 55- and 149-bp, while the T allele was uncut.

\section{Statistical analyses}

The presence of Hardy-Weinberg equilibrium was tested by a $\chi^{2}$-test for goodness of fit. Differences in clinical variables (age, age of onset, number of episodes, years of education, and duration of illness) were assessed using t-tests. Differences in genotype and allele frequencies between the bipolar disorder group and the normal control group were evaluated using a $\chi^{2}$-test. In addition, we divided the bipolar disorder group into two groups according to presence of psychotic symptoms. We then used a $\chi^{2}$-test to compare the frequencies of genotype and allele of each subgroup with those of the normal control group. The possibility that the genotypes of the three candidate genes influenced severity of symptom (YMRS, BPRS) and longitudinal course of illness (age of onset, number of episodes) was assessed using one-way analysis of variance (ANOVA). The analysis was performed using Statistical Package for the Social Sciences version 12.0. To consider the multiple comparisons, a Bonferroni correction was applied. Thus the $p$ value for reaching significance is $0.0056(0.05 / 9)$. Posthoc power analysis using QUANTO 1.2.3 program (http://hydra.usc.edu/gxe) showed that for $\mathrm{G}$ allele frequency of 5-HT2A $-1438 \mathrm{~A} / \mathrm{G}$ of 0.049 , the power was 0.311 [case $=103$, control= 86; $\alpha=0.05$; odds ratio (OR) of $\mathrm{A} / \mathrm{G}$ and $\mathrm{G} / \mathrm{G}=1.685$; disease frequency $=0.01]$.

Table 1. Symptom and characteristic comparison between controls and patients with bipolar disorder

\begin{tabular}{|c|c|c|c|c|c|c|}
\hline \multirow{3}{*}{ Characteristic } & \multirow[b]{2}{*}{$\begin{array}{l}\text { Comparison subjects } \\
\qquad(\mathrm{N}=86)\end{array}$} & \multicolumn{3}{|c|}{ Patients with bipolar disorder } & \multirow{2}{*}{\multicolumn{2}{|c|}{ Analysis }} \\
\hline & & \multirow{2}{*}{$\begin{array}{l}\text { All patients } \\
(\mathrm{N}=103) \\
\text { Mean } \pm \mathrm{SD}\end{array}$} & \multirow{2}{*}{$\begin{array}{l}\text { Psychotic mania } \\
\text { patients }(\mathrm{N}=78) \\
\text { Mean } \pm \mathrm{SD}\end{array}$} & $\begin{array}{c}\text { Non-psychotic mania } \\
\text { patients }(\mathrm{N}=25)\end{array}$ & & \\
\hline & Mean \pm SD & & & Mean \pm SD & $\mathrm{t}$ & $\mathrm{p}$ \\
\hline Age at interview & $31.2 \pm 9.7$ & $33.7 \pm 10.6$ & $33.6 \pm 10.2$ & $34.0 \pm 11.9$ & 0.14 & $0.89^{\dagger}$ \\
\hline Age of onset & & $29.7 \pm 10.7$ & $29.7 \pm 10.6$ & $30.0 \pm 11.4$ & 0.09 & $0.93^{\ddagger}$ \\
\hline No. of episodes & & $1.99 \pm 1.91$ & $1.94 \pm 2.07$ & $2.13 \pm 1.36$ & 0.40 & $0.69^{\ddagger}$ \\
\hline Years of education & & $12.2 \pm 2.6$ & $12.2 \pm 2.7$ & $12.2 \pm 2.5$ & 0.02 & $0.99^{\ddagger}$ \\
\hline Duration of illness & & $49.6 \pm 65.2$ & $51.0 \pm 68.7$ & $42.4 \pm 44.1$ & 0.40 & $0.69^{\ddagger}$ \\
\hline Baseline YMRS & & $33.5 \pm 9.5$ & $34.0 \pm 9.0$ & $31.8 \pm 11.0$ & 0.89 & $0.37^{\ddagger}$ \\
\hline Baseline BPRS & & $21.2 \pm 8.7$ & $22.6 \pm 8.1$ & $16.6 \pm 9.2$ & 2.82 & $0.006^{* \ddagger}$ \\
\hline & $\%$ & $\mathrm{~N} \quad \%$ & $\mathrm{~N} \quad \%$ & $\mathrm{~N} \quad \%$ & $\chi^{2}(\mathrm{df}=2)$ & $\mathrm{p}$ \\
\hline Female (sex) & 40.7 & 55.3 & 56.4 & 52.0 & 4.17 & $0.12^{\dagger}$ \\
\hline
\end{tabular}

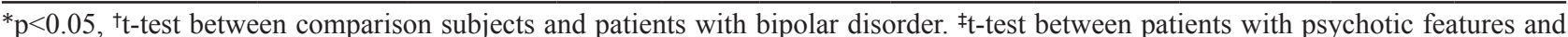
patients without psychotic features. SD: standard deviation, YMRS: Young Mania Rating Scale, BPRS: Brief Psychiatric Rating Scale 


\section{Results}

\section{Characteristics of the subjects}

There were no differences in age or gender distribution between the bipolar patient group and the control group (Table 1). There were no significant difference in age of onset, number of episodes, years of education, duration of illness, or baseline YMRS score between the psychotic mania group and the non-psychotic mania group. However, the psychotic mania group had significantly higher BPRS scores than the non-

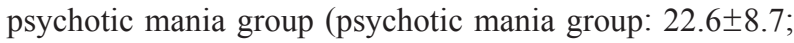
non-psychotic mania: 16.6 \pm 9.2 ).

\section{Genotype and allele frequencies of the three polymorphisms in the control and bipolar disorder groups}

The distribution of the 5-HTR2A 1438A/G, TPH 218A/C, and $\mathrm{TPH} 2$ 703G/T polymorphisms in bipolar patients and controls were in agreement with Hardy-Weinberg equilibrium. There were no significant statistical differences in the genotype distributions or allele frequencies of the three tested polymorphisms between the bipolar disorder group and the control group (Table 2).

\section{Genotype and allele frequencies of the three polymorphisms in the psychotic mania group and non-psychotic mania group}

Post-hoc tests did reveal differences in genotype distributions and allele frequencies of 5-HT2A -1438A/G polymorphism between the psychotic mania group and the non-psychotic mania group (Table 3). Moreover, there was a significant difference when we categorized genotype into two groups according to the presence of allele $\mathrm{G}$ (AA vs. $\mathrm{AG}+\mathrm{GG}, \chi^{2}=$ $6.83, \mathrm{p}=0.009)$ (Table 4). However, after applying the Bon-

Table 2. Genotype and allele frequencies in controls and patients with bipolar disorder

\begin{tabular}{|c|c|c|c|c|c|c|c|c|c|}
\hline \multirow{2}{*}{$\begin{array}{l}\text { 5-HT2A receptor gene } \\
\text { promoter }-1438 \mathrm{~A} / \mathrm{G}\end{array}$} & \multicolumn{3}{|c|}{ Genotype } & \multicolumn{2}{|c|}{ Analysis } & \multicolumn{2}{|c|}{ Allele } & \multicolumn{2}{|c|}{ Analysis } \\
\hline & $\mathrm{A} / \mathrm{A}$ & $\mathrm{A} / \mathrm{G}$ & $\mathrm{G} / \mathrm{G}$ & $\chi^{2}(\mathrm{df}=2)$ & $\mathrm{p}$ & A & G & $\chi^{2}(\mathrm{df}=1)$ & $\mathrm{p}$ \\
\hline \multirow[t]{2}{*}{ Comparison subjects $(\mathrm{N}=86)$} & 27 & 38 & 21 & 3.01 & 0.223 & 92 & 80 & 0.75 & 0.388 \\
\hline & $31.4 \%$ & $44.2 \%$ & $24.4 \%$ & & & $53.5 \%$ & $46.5 \%$ & & \\
\hline Patients with bipolar disorder & 22 & 57 & 24 & & & 101 & 105 & & \\
\hline All patients $(\mathrm{N}=103)$ & $21.3 \%$ & $55.3 \%$ & $23.3 \%$ & & & $49.0 \%$ & $51.0 \%$ & & \\
\hline Patients with psychotic & 12 & 45 & 21 & 7.50 & $0.024^{*}$ & 69 & 87 & 5.92 & $0.015^{*}$ \\
\hline Features $(\mathrm{N}=78)$ & $15.4 \%$ & $57.7 \%$ & $26.9 \%$ & & & $44.2 \%$ & $55.8 \%$ & & \\
\hline Patients without psychotic & 10 & 12 & 3 & & & 32 & 18 & & \\
\hline Features $(\mathrm{N}=25)$ & $40.0 \%$ & $48.0 \%$ & $12.0 \%$ & & & $64.0 \%$ & $36.0 \%$ & & \\
\hline TPH1 gene promoter $-218 \mathrm{~A} / \mathrm{C}$ & $\mathrm{A} / \mathrm{A}$ & $\mathrm{A} / \mathrm{C}$ & $\mathrm{C} / \mathrm{C}$ & $\chi^{2}(\mathrm{df}=2)$ & $\mathrm{p}$ & $\mathrm{A}$ & $\mathrm{C}$ & $\chi^{2}(\mathrm{df}=1)$ & $\mathrm{p}$ \\
\hline \multirow[t]{2}{*}{ Comparison subjects $(\mathrm{N}=86)$} & 28 & 39 & 19 & 0.187 & 0.911 & 95 & 77 & 0.203 & 0.652 \\
\hline & $32.6 \%$ & $45.3 \%$ & $22.1 \%$ & & & $55.2 \%$ & $44.8 \%$ & & \\
\hline Patients with bipolar disorder & 31 & 47 & 25 & & & 109 & 97 & & \\
\hline All patients $(\mathrm{N}=103)$ & $30.1 \%$ & $45.6 \%$ & $24.3 \%$ & & & $52.9 \%$ & $47.1 \%$ & & \\
\hline Patients with psychotic & 26 & 36 & 16 & 3.01 & 0.222 & 88 & 68 & 3.16 & 0.076 \\
\hline Features $(\mathrm{N}=78)$ & $33.3 \%$ & $46.2 \%$ & $20.5 \%$ & & & $56.4 \%$ & $43.6 \%$ & & \\
\hline Patients without Psychotic & 5 & 11 & 9 & & & 21 & 29 & & \\
\hline Features $(\mathrm{N}=25)$ & $20.0 \%$ & $44.0 \%$ & $36.0 \%$ & & & $42.0 \%$ & $48.0 \%$ & & \\
\hline TPH 2 gene promoter $-703 \mathrm{G} / \mathrm{T}$ & $\mathrm{G} / \mathrm{G}$ & $\mathrm{G} / \mathrm{T}$ & $\mathrm{T} / \mathrm{T}$ & $\chi^{2}(\mathrm{df}=2)$ & $\mathrm{p}$ & $\mathrm{G}$ & $\mathrm{T}$ & $\chi^{2}(\mathrm{df}=1)$ & $\mathrm{p}$ \\
\hline \multirow[t]{2}{*}{ Comparison subjects $(\mathrm{N}=86)$} & 17 & 40 & 29 & 1.48 & 0.477 & 74 & 98 & 0.782 & 0.376 \\
\hline & $8.1 \%$ & $46.5 \%$ & $33.7 \%$ & & & $43.0 \%$ & $57.0 \%$ & & \\
\hline Patients with bipolar disorder & 28 & 42 & 33 & & & 98 & 108 & & \\
\hline All patients $(\mathrm{N}=103)$ & $27.2 \%$ & $40.8 \%$ & $30.0 \%$ & & & $47.6 \%$ & $52.4 \%$ & & \\
\hline Patients with psychotic & 22 & 31 & 25 & 0.207 & 0.902 & 75 & 81 & 0.065 & 0.798 \\
\hline Features $(\mathrm{N}=78)$ & $28.2 \%$ & $39.7 \%$ & $32.1 \%$ & & & $48.1 \%$ & $51.9 \%$ & & \\
\hline Patients without psychotic & 6 & 11 & 8 & & & 23 & 27 & & \\
\hline Features $(\mathrm{N}=25)$ & $24.0 \%$ & $44.0 \%$ & $32.0 \%$ & & & $46.0 \%$ & $54.0 \%$ & & \\
\hline
\end{tabular}

${ }^{*} \mathrm{p}<0.05$, after Bonferroni correction significance dissapeared. TPH: tryptophan hydroxylase 
Table 3. Genotype and allele frequencies in psychotic bipolar disorder group and non-psychotic bipolar disorder group, according to 5-HT2A 1438A/G polymorphism

\begin{tabular}{|c|c|c|c|c|c|}
\hline \multirow{2}{*}{$\begin{array}{l}\text { 5-HT2A receptor gene } \\
\text { promoter }-1438 \mathrm{~A} / \mathrm{G}\end{array}$} & \multicolumn{3}{|c|}{ Genotype } & \multicolumn{2}{|c|}{ Allele } \\
\hline & $\mathrm{A} / \mathrm{A}$ & $\mathrm{A} / \mathrm{G}$ & $\mathrm{G} / \mathrm{G}$ & $\mathrm{A}$ & $\mathrm{G}$ \\
\hline \multirow[t]{2}{*}{ Comparison subjects $(\mathrm{N}=86)$} & 27 & 38 & 21 & 92 & 80 \\
\hline & $21.3 \%$ & $55.3 \%$ & $23.3 \%$ & $49.0 \%$ & $51.0 \%$ \\
\hline Patients with psychotic & 12 & 45 & 21 & 69 & 87 \\
\hline Features $(\mathrm{N}=78)$ & $15.4 \%$ & $57.7 \%$ & $26.9 \%$ & $44.2 \%$ & $55.8 \%$ \\
\hline Patients without psychotic & 10 & 12 & 3 & 32 & 18 \\
\hline \multirow[t]{2}{*}{ Features $(\mathrm{N}=25)$} & $40.0 \%$ & $48.0 \%$ & $12.0 \%$ & $64.0 \%$ & $36.0 \%$ \\
\hline & $\chi^{2}$ & $\mathrm{p}$ & & $\chi^{2}$ & $\mathrm{p}$ \\
\hline $\mathrm{C}$ vs. $\mathrm{P}+\mathrm{N}$ & 9.55 & 0.049 & & 6.67 & 0.036 \\
\hline C vs. P & 5.98 & 0.050 & & 2.81 & 0.094 \\
\hline C vs. N & 1.87 & 0.392 & & 1.74 & 0.188 \\
\hline P vs. N & 7.50 & $0.024^{*}$ & & 5.92 & $0.015^{*}$ \\
\hline
\end{tabular}

${ }^{*} \mathrm{p}<0.05$, but after Bonferroni correction significance dissapeared. C: comparison subjects, P: patients with psychotic features, N: Patients without psychotic features

Table 4. Odds ratio for having psychotic features in patients with bipolar disorder

\begin{tabular}{|c|c|c|c|c|c|c|}
\hline 5-HT2A -1438A/G & Psychotic mania & Nonpsychotic mania & OR & $95 \% \mathrm{CI}$ & $x^{2}$ & $\mathrm{p}$ \\
\hline $\mathrm{A} / \mathrm{A}$ & 12 & 10 & 1 & NA & & \\
\hline $\mathrm{A} / \mathrm{G}$ & 45 & 12 & 3.13 & $1.09-8.96$ & & \\
\hline $\mathrm{G} / \mathrm{G}$ & 21 & 3 & 5.83 & $1.34-25.43$ & & \\
\hline $\mathrm{A} / \mathrm{G}+\mathrm{G} / \mathrm{G}$ & 66 & 15 & 3.66 & $1.33-10.10$ & 6.83 & $0.009 *+$ \\
\hline
\end{tabular}

${ }^{*} \mathrm{p}<0.05$, but after Bonferroni correction significance dissapeared, ${ }^{+} \chi^{2}$ test between $\mathrm{A} / \mathrm{A}$ and $\mathrm{A} / \mathrm{G}+\mathrm{G} / \mathrm{G}$. NA: not applicable, OR: odds ratio, CI: confidence interval

ferroni correction, the difference in genotype distributions disappeared $(\alpha=0.0056)$. No differences in either genotype distribution or allele frequencies of TPH1 -218A/C and TPH2 $-703 \mathrm{G} / \mathrm{T}$ between the psychotic mania group and the non-psychotic mania group were observed.

\section{Comparison of the characteristics of bipolar disorder according to the three polymorphisms}

Symptom severity differences among the genotypes were also compared (Table 5). For the three gene polymorphisms, there were no significant differences in baseline BPRS, YMRS, age of onset, or number of episodes.

\section{Discussion}

We hypothesized that serotonin-related gene polymorphisms might affect the appearance of psychotic features in patients with bipolar disorder. Even though we failed to show a statistically significant result, the present study suggested that the 5 -HT2A receptor gene promoter $-1438 \mathrm{~A} / \mathrm{G}$ polymorphism might be associated with the presence of psychotic features in patients with bipolar disorder. Our result suggested that presence of the G allele could be associated with psychotic feature in bipolar disorder.
There is some evidence that the 5-HT2A receptor affects the psychotic symptoms in psychiatric disorders. However, the relationship between the 5-HT2A receptor and affective disorders with psychotic features has not been investigated. In schizophrenia, activation of 5-HT2A receptors in the prefrontal cortex may contribute to psychotic symptoms by enhancing the excitation of the descending glutamate neuron, which excites the mesolimbic dopamine neuron it innervates downstream. ${ }^{28,29}$ Both N-methyl-D-aspartate antagonist state (ketamine) and 5-HT2A agonist state (N,N-dimethyltryptamine, DMT) have been suggested as an appropriate model for psychoses. However, the two models have a difference in symptomatology. In the DMT model, positive symptoms are almost more prominent than negative symptoms. In the ketamine model for schizophrenia, on the other hand, phenomena that resemble cognitive symptoms, negative symptoms, and catatonic symptoms of schizophrenia were more prominent than they were in the DMT model for schizophrenia. ${ }^{30}$ We could therefore argue that the 5-HT2A agonist model is more apt for explaining the psychotic features in bipolar disorder. In order to explain the results of our study, we could assume that 5-HT2A promoter $-1438 \mathrm{~A} / \mathrm{G}$ polymorphism affected the promoter activity or expression of the 5-HT2A receptor during manic episodes. In detail, allele -G at 5-HT2A gene promoter 
Table 5. Comparison of clinical variables in bipolar disorder

\begin{tabular}{|c|c|c|c|c|c|}
\hline \multirow{2}{*}{$\begin{array}{l}\text { 5-HT2A receptor gene } \\
\text { promoter }-1438 \mathrm{~A} / \mathrm{G}\end{array}$} & \multicolumn{3}{|c|}{ Genotype } & \multicolumn{2}{|c|}{ ANOVA } \\
\hline & $\mathrm{A} / \mathrm{A}$ & $\mathrm{A} / \mathrm{G}$ & $\mathrm{G} / \mathrm{G}$ & $\mathrm{F}$ & $\mathrm{p}$ \\
\hline Age of onset & $26.4 \pm 8.8$ & $31.2 \pm 11.6$ & $29.3 \pm 9.9$ & 1.517 & 0.225 \\
\hline No. of episode & $2.0 \pm 1.9$ & $2.3 \pm 2.1$ & $1.4 \pm 1.5$ & 1.564 & 0.215 \\
\hline Baseline YMRS & $37.3 \pm 11.6$ & $33.3 \pm 8.2$ & $30.3 \pm 9.2$ & 2.869 & 0.062 \\
\hline Baseline BPRS & $22.4 \pm 10.9$ & $21.6 \pm 8.1$ & $19.1 \pm 7.8$ & 0.826 & 0.442 \\
\hline TPH1 gene promoter-218A/C & $\mathrm{A} / \mathrm{A}$ & $\mathrm{A} / \mathrm{C}$ & $\mathrm{C} / \mathrm{C}$ & $\mathrm{F}$ & $\mathrm{p}$ \\
\hline Age of onset & $31.7 \pm 11.5$ & $30.4 \pm 11.2$ & $25.3 \pm 7.1$ & 2.402 & 0.096 \\
\hline No. of episode & $1.8 \pm 1.7$ & $2.1 \pm 2.0$ & $2.0 \pm 2.2$ & 0.212 & 0.810 \\
\hline Baseline YMRS & $34.0 \pm 11.0$ & $33.5 \pm 7.9$ & $32.7 \pm 10.6$ & 0.110 & 0.896 \\
\hline Baseline BPRS & $21.1 \pm 8.3$ & $22.4 \pm 7.5$ & $18.7 \pm 11.3$ & 1.134 & 0.327 \\
\hline TPH2 gene promoter-703G/T & $\mathrm{G} / \mathrm{G}$ & $\mathrm{G} / \mathrm{T}$ & $\mathrm{T} / \mathrm{T}$ & $\mathrm{F}$ & $\mathrm{p}$ \\
\hline Age of onset & $29.1 \pm 10.5$ & $30.9 \pm 12.0$ & $28.6 \pm 9.2$ & 0.447 & 0.641 \\
\hline No. of episode & $1.6 \pm 1.8$ & $2.0 \pm 1.8$ & $2.3 \pm 2.2$ & 0.827 & 0.440 \\
\hline Baseline YMRS & $33.3 \pm 10.4$ & $32.9 \pm 9.7$ & $34.5 \pm 8.6$ & 0.250 & 0.780 \\
\hline Baseline BPRS & $23.9 \pm 10.1$ & $20.7 \pm 8.4$ & $19.9 \pm 7.9$ & 1.305 & 0.277 \\
\hline
\end{tabular}

YMRS: Young Mania Rating Scale, BPRS: Brief Psychiatric Rating Scale, ANOVA: analysis of variance

-1438 may have increased the expression of 5-HT2A receptors during manic episodes, thereby predisposing the 5-HT2A agonist state that produced the psychotic features. However, previous studies investigating the promoter activity of the 5-HT2A -1438A/G polymorphism did not support this hypothesis. Spurlock et al. ${ }^{31}$ reported that there was no functional difference between allele $A$ and allele $G$ at 1438 locus in promoter activity. Yet in 2002, Myers et al. ${ }^{32}$ demonstrated that in vitro assays showed neither A- nor G-allele of -1438 locus had significant effects on promoter activity when expressed with the major alleles at $1420 \mathrm{C} / \mathrm{T}$ and $-783 \mathrm{~A} / \mathrm{G}$. However, promoter activity was decreased significantly when minor allele G at 783 was expressed with G- allele at -1438 .

Another possible explanation is that the decreased activity of the 5-HT2A receptor, due to the polymorphism of the 5-HT2A receptor gene, affects the 5HT2A-dopamine interaction to decrease the ability to stabilize the dopamine activity. Activation of the 5-HT2A receptor decreases the activity of dopaminergic neurons in the ventral tegmental area via gamma-aminobutyric acid interneurons. ${ }^{33}$ The psychotic manic state is supposed to be a hyperdopaminergic state. If the polymorphism in the 5-HT2A gene decreased the activity of 5-HT2A, it would become the vulnerable gene for psychosis.

We simultaneously investigated the association between three serotonin-related gene polymorphisms and bipolar disorder. To our knowledge, this is the first association study between TPH2 -703G/T polymorphisms and bipolar disorder in the Korean population. We found no association between TPH2 and bipolar disorder.

An example of gene-gene interaction was recently reported when Lin et al. ${ }^{34}$ demonstrated that TPH1 interacts with
TPH2 to modify the risk for bipolar disorder. Those with the TPH2 at-risk TAG haplotype have the OR of 3.73 for developing bipolar disorder. Yet, if combined with TPH1 -346G allele or TPH1 -346T, the odds ratio for bipolar disorder becomes 4.81 or 1.68 , respectively. ${ }^{34}$ The presence of gene-gene interaction may explain why the results of association studies are inconsistent. In the future, efforts directed toward finding both gene-gene interactions and candidate genes for bipolar disorder are necessary.

A recent meta-analysis suggested that the homozygous genotype of the TPH A218C polymorphism may increase the risk for bipolar disorder. ${ }^{18}$ However, our study also suggested that the TPH1 A218C polymorphism was not associated with bipolar disorder.

In 2001, Oh et al. ${ }^{35}$ investigated the association between the 5-HT2A receptor gene promoter $-1438 \mathrm{~A} / \mathrm{G}$ polymorphism and bipolar disorder in the Korean population. They suggested that the A allele is significantly more frequent in patients with bipolar disorder when compared to normal controls. In the present study, however, the 5-HTR2A 1438A/G polymorphisms were not associated with bipolar disorder.

We hypothesized that the 5-HT2A -1438A/G polymorphism might alter the longitudinal course of the illness. Yet including 5-HT2A, none of the three serotonin-related gene polymorphisms altered either mean age of onset or number of episodes.

It is worth noting the weaknesses of the present study. First, we interviewed the patients and their first-degree relatives during their admissions and collected information about past history of affective episodes and the duration of illness. Consequently, we could not control recall bias. During manic 
episodes, patients and their families tended to remember previous manic episodes more than depressive episodes, possibly causing the number of depressive episodes to be underestimated. Second, the relatively small sample size limited the power of investigating the possible associations between the above serotonin-related gene polymorphisms and bipolar disorder.

In conclusion, we failed to found the statistically significant association between three polymorphisms and bipolar disorder. However, there was a trend towards association between 5-HT2A -1438A/G polymorphism and psychotic symptom in bipolar disorder. In future studies, large sample sizes should be used to confirm our results.

\section{-Acknowledgments}

This study was supported by a grant from the Korea Health 21 R\&D Project, Ministry of Health and Welfare, Republic of Korea (A040042). This paper was done as part of the master's thesis (in medicine) of Dr. K-Y Choi.

\section{REFERENCES}

1. Merikangas KR, Akiskal HS, Angst J, Greenberg PE, Hirschfeld RM, Petukhova M, et al. Lifetime and 12-month prevalence of bipolar spectrum disorder in the National Comorbidity Survey replication. Arch Gen Psychiatry 2007;64:543-552.

2. McGuffin P, Rijsdijk F, Andrew M, Sham P, Katz R, Cardno A. The heritability of bipolar affective disorder and the genetic relationship to unipolar depression. Arch Gen Psychiatry 2003;60:497-502.

3. Arranz MJ, Munro J, Owen MJ, Spurlock G, Sham PC, Zhao J, et al. Evidence for association between polymorphisms in the promoter and coding regions of the 5-HT2A receptor gene and response to clozapine. Mol Psychiatry 1998;3:61-66.

4. Parsons MJ, D’Souza UM, Arranz MJ, Kerwin RW, Makoff AJ. The -1438A/G polymorphism in the 5-hydroxytryptamine type $2 \mathrm{~A}$ receptor gene affects promoter activity. Biol Psychiatry 2004;56:406-410.

5. Chee IS, Lee SW, Kim JL, Wang SK, Shin YO, Shin SC, et al. 5-HT2A receptor gene promoter polymorphism $-1438 \mathrm{~A} / \mathrm{G}$ and bipolar disorder. Psychiatr Genet 2001;11:111-114.

6. Ohara K, Nagai M, Tsukamoto T, Tani K, Suzuki Y. 5-HT2A receptor gene promoter polymorphism-1438G/A and mood disorders. Neuroreport 1998;9:1139-1141.

7. Etain B, Rousseva A, Roy I, Henry C, Malafosse A, Buresi C, et al. Lack of association between 5-HT2A receptor gene haplotype, bipolar disorder and its clinical subtypes in a West European sample. Am J Med Genet B Neuropsychiatr Genet 2004;129B:29-33.

8. Zhang HY, Ishigaki T, Tani K, Chen K, Shih JC, Miyasato K, et al. Serotonin2A receptor gene polymorphism in mood disorders. Biol Psychiatry 1997;41:768-773.

9. Jequier E, Robinson DS, Lovenberg W, Sjoerdsma A. Further studies on tryptophan hydroxylase in rat brainstem and beef pineal. Biochem Pharmacol 1969;18:1071-1081.

10. Patel PD, Pontrello C, Burke S. Robust and tissue-specific expression of TPH2 versus TPH 1 in rat raphe and pineal gland. Biol Psychiatry 2004;55:428-433.

11. Walther DJ, Bader M. A unique central tryptophan hydroxylase isoform. Biochem Pharmacol 2003;66:1673-1680.

12. Bellivier F, Leboyer M, Courtet P, Buresi C, Beaufils B, Samolyk D, et al. Association between the tryptophan hydroxylase gene and manic-depressive illness. Arch Gen Psychiatry 1998;55:33-37.

13. Nielsen DA, Virkkunen M, Lappalainen J, Eggert M, Brown GL, Long JC, et al. A tryptophan hydroxylase gene marker for suicidality and alcoholism. Arch Gen Psychiatry 1998;55:593-602.

14. Manuck SB, Flory JD, Ferrell RE, Dent KM, Mann JJ, Muldoon MF. Aggression and anger-related traits associated with a polymorphism of the tryptophan hydroxylase gene. Biol Psychiatry 1999;45:603-614.

15. Yoon HK, Kim YK. Association between serotonin-related gene polymorphisms and suicidal behavior in depressive patients. Prog Neuropsychopharmacol Biol Psychiatry 2008;32:1293-1297.

16. Lalovic A, Turecki G. Meta-analysis of the association between tryptophan hydroxylase and suicidal behavior. Am J Med Genet 2002;114: 533-540.

17. Lai TJ, Wu CY, Tsai HW, Lin YM, Sun HS. Polymorphism screening and haplotype analysis of the tryptophan hydroxylase gene (TPH1) and association with bipolar affective disorder in Taiwan. BMC Med Genet $2005 ; 6: 14$.

18. Chen C, Glatt SJ, Tsuang MT. The tryptophan hydroxylase gene influences risk for bipolar disorder but not major depressive disorder: results of meta-analyses. Bipolar Disord 2008;10:816-821.

19. Walther DJ, Peter JU, Bashammakh S, Hörtnagl H, Voits M, Fink H, et al. Synthesis of serotonin by a second tryptophan hydroxylase isoform. Science 2003;299:76.

20. Yoon HK, Kim YK. TPH2 -703G/T SNP may have important effect on susceptibility to suicidal behavior in major depression. Prog Neuropsychopharmacol Biol Psychiatry 2009;33:403-409.

21. Lopez VA, Detera-Wadleigh S, Cardona I, Kassem L, McMahon FJ. Nested association between genetic variation in tryptophan hydroxylase II, bipolar affective disorder, and suicide attempts. Biol Psychiatry 2007;61:181-186.

22. Grigoroiu-Serbanescu M, Diaconu CC, Herms S, Bleotu C, Vollmer J, Muhleisen TW, et al. Investigation of the tryptophan hydroxylase 2 gene in bipolar I disorder in the Romanian population. Psychiatr Genet 2008;18:240-247.

23. De Luca V, Likhodi O, Van Tol HH, Kennedy JL, Wong AH. Tryptophan hydroxylase 2 gene expression and promoter polymorphisms in bipolar disorder and schizophrenia. Psychopharmacology (Berl) 2005; 183:378-382.

24. APA (American Psychological Association). Diagnostic and statistical manual of mental disorders, 4th edition. Washington DC: American Psychiatric Press; 1994.

25. First M, Spitzer RL, Gibbon M, William JB. Structured clinical Interview for DSM-IV Axis I Disorder-Patient Edition (SCID-I/NP, version 2.0), New York: Biometrics Research Department, New York State Psychiatric Institute; 1998.

26. Young RC, Biggs JT, Ziegler VE, Meyer DA. A rating scale for mania: reliability, validity and sensitivity. Br J Psychiatry 1978;133:429-435.

27. Bech P, Larsen JK, Andersen J. The BRPS: psychometric developments. Psychopharmacol Bull 1988;24:118-121.

28. Stahl SM. Sahl's essential psychopharmacology, neuroscientific basis and practical applications. 3rd edition. New York: Cambridge U.P. 2008, p.359-361.

29. Glenthoj BY, Mackeprang T, Svarer C, Rasmussen H, Pinborg LH, Friberg L, et al. Frontal dopamine $\mathrm{D}(2 / 3)$ receptor binding in drugnaive first-episode schizophrenic patients correlates with positive psychotic symptoms and gender. Biol Psychiatry 2006;60:621-629.

30. Gouzoulis-Mayfrank E, Heekeren K, Neukirch A, Stoll M, Stock C, Daumann J, et al. Inhibition of return in the human 5HT2A agonist and NMDA antagonist model of psychosis. Neuropsychopharmacology 2006;31:431-441.

31. Spurlock G, Heils A, Holmans P, Williams J, D’Souza UM, Cardno A, et al. A family based association study of T102C polymorphism in 5HT2A and schizophrenia plus identification of new polymorphisms in the promoter. Mol Psychiatry 1998;3:42-49.

32. Myers RL, Airey DC, Manier DH, Shelton RC, Sanders-Bush E. Polymorphisms in the regulatory region of the human serotonin 5-HT2A receptor gene (HTR2A) influence gene expression. Biol Psychiatry 2007; 61:167-173. 
33. Stahl SM. Stahl's essential psychopharmacology-neuroscientific basis and practical application. 3rd edition. Cambridge. 2008, p.484.

34. Lin YM, Chao SC, Chen TM, Lai TJ, Chen JS, Sun HS. Association of functional polymorphisms of the human tryptophan hydroxylase 2 gene with risk for bipolar disorder in Han Chinese. Arch Gen Psychi- atry 2007;64:1015-1024.

35. Oh SY, Chee IS, Lee YH. Association between 5-HT2A receptor gene promoter $-1438 \mathrm{~A} / \mathrm{G}$ polymorphism and bipolar disorder in a Korean population Korean Neuropsychiatric Association 2001;40:81-86. 